\title{
15
}

\section{THE NATIONAL PARTY OF AUSTRALIA}

\author{
Geoff Cockfield
}

By early 2019, the Nationals looked set to lose ground in the forthcoming election. There were the usual problems of shrinking rurality in electorates along the eastern mainland coast and impending competition from minor parties, Independents and, in some regions, the Liberals. The Coalition was lagging in the opinion polls and the Nationals had struggled to articulate positions for-and in some cases develop substantial policies on-some key rural issues such as water allocations, mining developments, migration and the state of the dairy industry. More unusually, the federal Nationals were also in the mainstream news with three federal parliamentary members subject to scrutiny and ridicule for their personal behaviour, an unplanned leadership change, talk of further leadership challenges and pre-election criticisms of Coalition policy by Nationals' candidates.

Yet, in the national election, the Nationals held all their House of Representatives seats and even increased their hold on the most marginal seats. The aim of this chapter is to try to explain this, considering the focuses of the campaign, strategies around preferences and policy issues and what the party represented to rural and regional voters. In summary, the Nationals were able to restore some internal stability prior to the election, concentrate resources and messaging on the seats they held and do advantageous preference deals. The result demonstrated that the Nationals, and perhaps the Coalition more generally, can have a degree of dysfunction and a limited policy agenda and still attract sufficient votes to be in government, provided they seem to represent particular values and positions. 


\section{The candidates}

The Nationals contested 29 House of Representatives seats-close to the same number as in 2016. Through the Queensland Liberal National Party (LNP), there were seven 'Nationals' ${ }^{1}$ candidates running in winnable seats, with six of those successful. The Victorian party also concentrated its efforts, contesting only four seats (for three wins). The Nationals did not run candidates in the Labor-held seats of McEwen (peri-urban), Ballarat and Bendigo (based on regional cities), as they had in 2016. ${ }^{2}$ In New South Wales for this election, the State party was slightly more aggressive and competed with the Liberals for the regional seats of Gilmore and Eden-Monaro. The Nationals had not contested Gilmore for 40 years and the party has never held Eden-Monaro. The South Australian Nationals, a party that was revived in the 1960s after being extinguished through a merger in 1932, made a rare foray into the federal sphere, contesting the seat of Barker. The Tasmanian National Party returned to the federal arena for the first time since 1996. The State party was re-established in 2018, with candidates selected for three seats (Bass, Braddon and Lyons) and two others for the Senate for the 2019 election. In Western Australia, following concerted but unsuccessful attempts to re-establish a presence in the federal parliament in 2013 and 2016, the State Nationals scaled back their efforts in 2019, contesting only three seats (Durack, O'Connor and Pearce), covering the wheat belt and the northern and western remote areas.

As in recent elections, in 2019, the most common background of candidates was in small-medium regional businesses, with 25 of the 39 candidates ( 10 for the Senate) in this category. There were two candidates who could be considered primarily commercial farmers, with only Mark Coulton (Parkes) making it into parliament, though many more candidates had rural backgrounds and interests, including agricultural landholding. Both Nationals Leader Michael McCormack and Deputy Leader Bridget McKenzie are somewhat typical of the modern

1 LNP candidates, like those from the Country Liberal Party (CLP), affiliate with one or the other of the federal Coalition parties after an election, though intending allegiances are usually signalled during the campaign.

2 Under Coalition agreements in Victoria and New South Wales, either party may contest any seat where there is no sitting member recontesting. In reality, such contests are restricted to regional and rural electorates. 
Nationals, having lived and worked in regional areas but being one or two generations removed from the farm. Despite this, or perhaps because of it, they are both great supporters of farming people and communities.

Less than 20 per cent of the candidates for lower house seats were women, with only two contesting winnable seats (Capricornia and Mallee). Michelle Landry increased her margin in Capricornia, while Anne Webster became the new member for Mallee. Webster was preselected for Mallee after the previous member, the married Andrew Broad, stepped aside after personal exchanges with a woman on an international 'dating' website made the news in early 2019 (Wroe and Crowe 2018). The Nationals continued to use Senate preselections to address their historical gender imbalance. In 2019, six of their 10 Senate candidates were women, with Susan McDonald from Queensland, Perin Davey from New South Wales and Sam McMahon from the Northern Territory elected, so that four of the Nationals' five post-election senators were women. Davey's campaign was somewhat disrupted by attempts to encourage below-the-line voting to elevate the chances of the fourth listed Liberal, Jim Molan. Had the Molan support campaign succeeded, the Nationals would have been without a senator in New South Wales, even though that State party is strongly coalitionist. After the election there were a record seven women in the 21-member federal party room. The Nationals continued with a woman Deputy Leader, Bridget McKenzie, who had followed from former NSW Senator Fiona Nash in that role.

The Nationals were at risk of losing support among rural and regional women because of the Broad story, former leader Barnaby Joyce's marital breakdown and relationship with a staffer (Livingston 2018) and a complaint of inappropriate behaviour against Joyce (Chan 2018). Joyce's situation led to him vacating the party's leadership in early 2018. Efforts to preselect more women were probably influenced by the need to clean up their image, but the Nationals may also have been recognising the importance of women in regional small business, farm businesses and community and industry organisations and more general social change. 


\section{Policies and the campaign}

The Nationals entered the 2019 election trying to balance a number of politically difficult issues and some of these were addressed through campaign policy statements (see Table 15.1 for a summary of positions). First, while mining developments offer the prospect of regional jobs, there are many rural people opposed to them generally or in the particular. Despite some previous vacillation, the National Party ended the 2019 election campaign as a strong supporter of mining. There were two aspects to this: the Nationals held and continued to hold after the election the resources portfolio, under Senator Matt Canavan (from Queensland), which has a strong development focus; and, second, for many regional areas, especially in Queensland, mining investment is one of the few industries that offers the prospect of additional jobs. Nationals members in central Queensland seats (Capricornia, Herbert, Flynn and Dawson) made a proposed coalmining development by Indian company Adani and the related jobs a central issue (Murphy 2019a). Local campaign advertising highlighted Queensland Labor's and federal Labor's vacillations on support for the development, while candidates even welcomed the confrontations that came from a pre-election anti-Adani protest roadshow led by former Greens leader Bob Brown (Koziol 2019). These candidates and other members of the Queensland LNP staked out a more general pro-coal position, with some even implying just before the election that they would split from the Coalition unless the Cabinet committed to support and even fund a new coal-fired power station in north Queensland. Scott Morrison adroitly defused this with a promise to 'evaluate' the case (Coorey 2019).

\section{Table 15.1 Summary of issues, Nationals campaign positions} and Coalition policy positions

\begin{tabular}{|l|l|l|}
\hline Issue & Nationals position & Coalition position \\
\hline $\begin{array}{l}\text { Adani (Carmichael) } \\
\text { coalmine proposal }\end{array}$ & Full support and subsidies where needed & $\begin{array}{l}\text { Accelerated } \\
\text { approvals prior } \\
\text { to the election }\end{array}$ \\
\hline $\begin{array}{l}\text { New coal-fired } \\
\text { power stations }\end{array}$ & $\begin{array}{l}\text { Prioritise a north Queensland facility and } \\
\text { subsidise if needed\# }\end{array}$ & $\begin{array}{l}\text { Evaluate the } \\
\text { feasibility }\end{array}$ \\
\hline $\begin{array}{l}\text { Murray-Darling } \\
\text { Basin (MDB) water } \\
\text { allocations }\end{array}$ & $\begin{array}{l}\text { Prioritise agriculture in allocations } \\
\text { Establish a national water grid }\end{array}$ & $\begin{array}{l}\text { Extend regional } \\
\text { development } \\
\text { funding in MDB } \\
\text { regions }\end{array}$ \\
\hline
\end{tabular}




\begin{tabular}{|l|l|l|}
\hline Issue & Nationals position & Coalition position \\
\hline Dairy industry & $\begin{array}{l}\text { Mandatory code of conduct for processors } \\
\text { Market information provision } \\
\text { Energy-efficiency grants } \\
\text { Grants for farmer cooperatives } \\
\text { Australian Competition and Consumer } \\
\text { Commission (ACCC) dairy specialist } \\
\text { More money for ACCC agriculture unit }\end{array}$ & Same as Nationals \\
\hline Migrant labour & $\begin{array}{l}\text { Enable working visas for those } \\
\text { in agriculture } \\
\text { Regional migrant visas } \\
\text { Overall reduction in migration }\end{array}$ & Same as Nationals \\
\hline Small business & $\begin{array}{l}\text { Lower taxes for small and medium-sized } \\
\text { enterprises } \\
\text { Protection from 'big' business* } \\
\text { Marketing support* } \\
\text { Women entrepreneur program* }\end{array}$ & $\begin{array}{l}\text { Lower business } \\
\text { taxes }\end{array}$ \\
\hline Vegan farm protests & $\begin{array}{l}\text { Increase penalties for property trespass } \\
\text { Enforce restrictions on published } \\
\text { farm information }\end{array}$ & $\begin{array}{l}\text { Promised legislation } \\
\text { (Foley 2019) }\end{array}$ \\
\hline
\end{tabular}

\# It was not clear whether or not all Nationals supported this.

* No detail, just general undertakings.

Source: Foley (2019); The Nationals (2019a, 2019b).

Second, the Murray-Darling Basin (MDB) Plan, which includes limiting water extractions, was also in the news, with allegations of fraudulent activities around government programs and reports of mass fish deaths (Davies 2019; Hamilton-Smith 2018). The Nationals wanted water policies that recognised 'the continued importance of agriculture' and included the building of more dams and the establishment of a national water grid under a statutory authority (The Nationals 2019a), which would be a major institutional change in Australia's federal system. In response to the fish deaths - and perhaps with the threat of the Shooters, Fishers and Farmers Party (SFFP) in mind ${ }^{3}$ - there were a number of promises to support recreational fishing (The Nationals 2019a). On the other hand, the Nationals stayed well away from any flirtation with changes to gun laws in the wake of the mass shootings in Christchurch, New Zealand. Prior to the massacre, some Coalition State governments and individual members, including the Deputy Leader, Bridget McKenzie, had engaged with gun lobbyists and were pushing for the 'easing' of some legislative restrictions on certain types of guns (Patel 2016).

3 The SFFP won two seats from the Nationals in the NSW State election earlier in 2019. 
Third, the Nationals have long struggled with what to do for farmers since the deregulation of commodity marketing support systems. The dairy industry was an election issue for the Nationals in 2016 and continuing low prices and drought made it evident that there had been little real policy change or impact since. For the 2019 election, the Nationals again supported a mandatory code of conduct-aimed largely at processorsand a range of other measures trying to influence prices in a market context (Table 15.1) (The Nationals 2019a).

A fourth policy dilemma for the Nationals is migration. They are generally nationalist and socially conservative but migrants and temporary workers are an increasingly important source of labour for agricultural industries and a potential source of more people in rural areas otherwise experiencing depopulation. For this election, the party supported 'multiculturalism', though with an emphasis on 'integration' and a proposal to encourage migrants to move to regional areas, but with the proviso that the focus would 'remain firmly on attracting skilled migrants' (The Nationals 2019b, emphasis added).

There were also some fundamental issues for the Nationals in the areas of small business and agriculture. There were general policy aspirations in support of small business (Table 15.1), but the centrepiece, and perhaps major Coalition policy, was tax cuts. For agriculture, there would be continued drought relief and promises about the benefits of forthcoming trade agreements. As with the Adani protests, a series of protests by vegan activists presented the Nationals with an opportunity to bolster their anti-post-materialist credentials, which played well in the regions. The animal welfare activism 'threat' would be addressed through increasing legal penalties (Table 15.1).

The overall approach for the campaign was for sitting members to focus on local concerns and agrarian and small business rhetoric and issues, supported by fearmongering about Labor and the Greens. Party Leader Michael McCormack spent much of his time in his electorate of Riverina, with two to three visits to central Queensland seats and one or two to Lyons and Braddon in Tasmania (Doran et al. 2019). He did not visit Western Australia, South Australia or the NSW north coast seat of Richmond, which was held by Labor but was a former Nationals stronghold. Scott Morrison was also active in visiting central Queensland-somewhat in contrast to the 2016 election, when Malcolm Turnbull's regional visits were limited and nearly always taken in tandem with Barnaby Joyce. 
Joyce kept a low national profile during the campaign, focusing on his electorate of New England and the revived threat of Independent Tony Windsor. This suggests, with the exception of the Tasmanian visits, that the focus was overwhelmingly on the winnable seats.

\section{Results}

The Nationals held all their House of Representatives seats and retained five senators (AEC 2019). As usual, the proportion of seats exceeded the proportion of votes (Figure 15.1), reflecting the geographical concentration of support and the focus of campaigning on a limited number of electorates. The proportion of House of Representatives seats declined very slightly due to an additional seat (making 151) in the parliament since the previous election. The Senate result was a closer reflection of overall support, with the Nationals ending up with 6.5 per cent of senators-less than the proportion for the Greens.

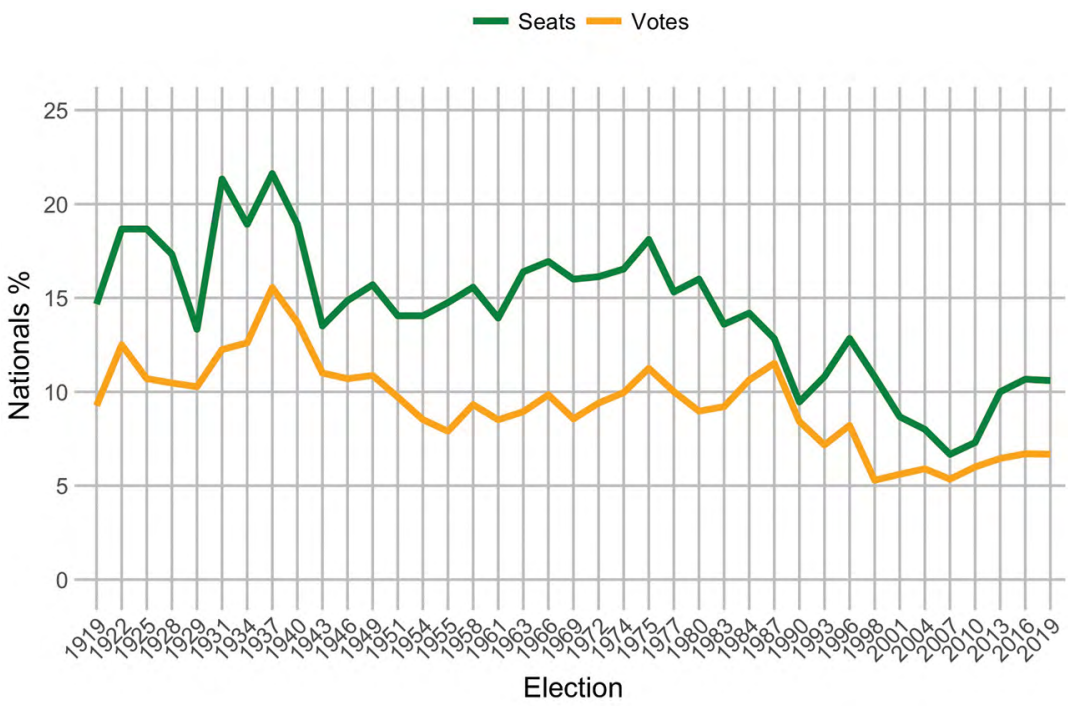

Figure 15.1 Country/National Party share of primary votes and seats for the House of Representatives at national elections

Note: LNP votes are divided between the Liberals and Nationals based on expected party alignment in Canberra, to analyse historical trends.

Sources: Adapted from UWA (various years); AEC (2019). 
The Nationals increased both their primary and their two-party-preferred (TPP) vote in nine of the 16 seats they won (AEC 2019). They increased just the primary vote in two seats and just the TPP margins in another two. In line with the overall Queensland result for the Coalition (discussed in Chapter 11, this volume), the Nationals substantially increased the TPP gaps in the previously marginal central Queensland seats of Capricornia, Dawson and Flynn. Most surprising was the result for Dawson, given that sitting member, George Christensen, was yet another National in the media spotlight—in his case for spending substantial periods, including parliamentary business periods, over the previous four years in the Philippines (Wroe 2019).

The Nationals finished the election with no seats with margins of less than 6.5 per cent, with Anne Webster having the narrowest margin, though should she choose to run again, she will not have competition from the Liberals and should increase this with a 'sophomore surge' (first-term incumbency bonus). In New South Wales, the SFFP had little impact on the Nationals' final outcomes, since, of the western NSW seats, the SFFP only contested Calare, for less than 18 per cent of the vote, and in that seat the Nationals increased their TPP vote. Indeed, the flurry of activity of the minor parties, including PHON and the UAP, may have worked in favour of the Nationals. The Coalition arranged a preference deal with the UAP while the Nationals-differing from most of the Liberal preference deals_elevated PHON above Labor. McCormack, in an unusual burst of honesty on preferences, said the party needed to do what it took to win, though he also argued that PHON was closer to the Nationals on values and policies than were Labor or, especially, the Greens (Murphy 2019a). This rapprochement with PHON carried some risk given that, during the previous term of government, there had been attempts by 'alt-right' groups to infiltrate the NSW Nationals, which led to some hasty expulsions (McGowan 2018).

The results did, however, reaffirm that the federal Nationals are confined to the eastern grain, sugar and dairy zones, with parts of the sugar and dairy zones slipping from their grasp over time with peri-urban development. Outside the seats the Nationals already held, attempts at expansion were very unsuccessful. In New South Wales the Nationals received less than 13 per cent of the primary vote in Gilmore and less than 7 per cent in Eden-Monaro, leaving the Liberal Party with significant rural representation in southern New South Wales. In Indi, the Nationals' vote decreased significantly to 9.5 per cent, suggesting that if Independent 
Helen Haines, successor to Cathy McGowan, is defeated at a future election, Indi will most likely return to the Liberals. Similarly, the Liberals are the dominant party in rural and remote South Australia, Tasmania and Western Australia. In Western Australia, the Nationals lost ground from the previous election in the three electorates they contested. For the Senate, the WA Nationals' vote share declined, with a quota well below that of PHON and below that for the Help End Marijuana Prohibition (HEMP) Party, as was also the case with the Tasmanian Nationals. For the Tasmanian electorates of Bass and Braddon, neither Nationals candidate received more than 3 per cent of the primary vote. In Lyons, Deanna Hutchinson won almost 16 per cent of the votes, but this was the electorate in which the Liberal candidate was disendorsed just before the election. In Barker (SA), Miles Hannemann won only 2.5 per cent of the vote. Thus, the 'revived' parties made little impression.

The results suggest that the only realistic intermediate prospect for expansion of the Nationals' footprint is Kennedy in Queensland. For the 2019 election, however, Bob Katter increased both his primary and his TPP votes, so regaining this seat for the Nationals looks set to hinge on the health and inclinations of the sitting member and perhaps the intentions of his son, Robbie Katter, who is a member of the Queensland Parliament. While three NSW coastal/rural seats all swung further to the Nationals, to the north in Richmond, the Nationals primary vote decreased slightly and Labor's Justine Elliot slightly increased her margin, suggesting this seat is no longer in the Nationals' heartland (for an explanation of demographic change in this region, see Cockfield 2009).

\section{Cabinet, Coalition and policy directions}

Once again, the Liberal Party needed the Nationals to form government. There have been only three elections since 1922 in which the Liberals (or their predecessor parties) could have governed alone (for a full review, see Botterill and Cockfield 2015). Despite the pre-election dissension from some Queensland parliamentarians (Clarke 2019), the Coalition parties had a reasonably harmonious campaign. The two leaders worked well together, and Scott Morrison was quite popular in regional areas. Post election, all indications are that the Nationals will settle into a collaborative approach under McCormack. There were at least two threats to a collaborative Coalition. First, Joyce remained in the party 
room and, prior to the election, indicated his interest in a return to the leadership (Crowe 2019). His style-in contrast to recent leaders such as John Anderson, Tim Fischer, Mark Vaile and probably McCormackwas to be more combative and openly independent within the Coalition.

Second, and related to Joyce's leadership ambitions, the Queensland Nationals MPs may be emboldened to engage in further bouts of 'independence', with, for example, some wanting to start debates about enabling nuclear power in Australia (Murphy 2019b), which could be politically risky for the Coalition. This may be part of a more general problem for the Coalition, with an assertive Queensland LNP developing its own agendas, rather than just feeding into the two Coalition parties at the federal level. While the LNP has not yet proved a successful party in terms of longevity in office at the State level, it is the dominant party in Queensland federally, holding more than two-thirds of Queensland's House of Representatives seats after the 2019 election.

Against that, Morrison is likely to have considerable authority within the joint party room, given his central role in the Coalition campaign, and McCormack is likely to favour quiet negotiation over flourishes of independence. Furthermore, the case for Joyce's return to the leadership may have been diminished by the election result. Joyce was not given a post-election ministerial position and did not even retain his role as drought envoy; and other possible leadership contenders, such as David Littleproud (Maranoa), who did become Deputy Leader when McKenzie stepped down in early 2020, were waiting in the wings, so a resurrection might not be a simple matter.

The Nationals have one less member of Cabinet, though they gained an additional outer ministry. Trade-so often in the past a portfolio of the Country (then National) Party-remains with the Liberals, however, the Nationals have water resources, as part of an omnibus portfolio, as well as infrastructure, which is a key area of concern for regional politics. Decentralisation remained a named part of MP for Gippsland Darren Chester's outer-ministry portfolio that also includes regional services and local government. Decentralisation was introduced to a portfolio in Morrison's first ministry and it remains to be seen whether this is more than just a symbolic naming. Efforts at decentralisation have previously been most associated with Labor governments (1945-49 and 1972-75). 


\section{Explaining the result}

Despite the internal ructions, unfavourable media related to personal behaviour and no great policy initiatives in the previous two terms of government, the Nationals were able to hold their ground. The Nationals and the Coalition more generally were able to establish a reasonable level of discipline just before the campaign proper, the preference deals seemed to work and competition from minor parties, such as the SFFP, was more limited than expected, probably partly due to resource constraints. Morrison was popular in the bush, especially after taking decisive action on recovery after severe floods in northern Queensland early in 2019, and he followed this up by making drought a priority immediately after he assumed the prime ministership (PM\&C 2018; Karp 2019). There was pork-barrelling around infrastructure and facilities in target electorates, but this may not have been decisive, given that, in the three most marginal seats of central Queensland, Labor's spending promises far exceeded those of the Nationals (Irvine and Wright 2019).

Perhaps this election suggests more about some general tendencies in national elections in Australia. The Coalition parties can win elections despite some degree of disunity, adverse perceptions of leadership, no great policy reforms and a thin policy agenda. Fearmongering about Labor and 'progressive' politics can work and may work especially well in regional areas. From a survey of attitudes and values, weighted to regional areas and conducted in 2016 by the author and others, there is evidence of the generally assumed social conservatism in the bush. Using some survey items adapted from the work of Shalom Schwartz (Schwartz et al. 2010, 2014), we examined the values of some 1,400 Australians, with 66 per cent of those recruited from regional areas. Factor reductions were used to identify related survey items, which were turned into scales about 'security and patriotism' and 'equality and freedom' - each constructed from three seven-point scale questions. We also asked a series of questions about attitudes towards climate change and these were converted to a scale from four seven-point scale questions. As expected, these constructed factors significantly correlated to voting intention at that time, prior to the 2016 election. Intending Liberal and Nationals voters had the highest scores on 'security and patriotism' and the lowest scores for 'equality and freedom' and 'concern about climate change'. 
For this chapter, I re-examined the data by dividing the respondents by electorate types: 'eastern rural' electorates, which included all the Nationals' electorates plus some adjacent ones held by the Liberal Party; 'other regional' electorates; and 'metropolitan' electorates. The average of ratings for 'security and patriotism' from respondents in the eastern rural electorates was higher than those from other areas, while that for 'equality and freedom' was lower. The differences in ratings were not great (see Figure 15.2), but they were statistically significant ( $\mathrm{p}$ values of 0.023 and 0.05 , respectively). While there were no significant differences for 'concern about climate change' by electorate type, there was a difference by State, with Queensland respondents having the lowest average rating. The key point from this is that the background narratives of the Coalition in recent years about nationalism, national security and the threat of Labor's 'equality' agenda may play particularly well in the Nationals' heartland. In addition, concerns about the climate change impacts of additional coalmines might be somewhat smaller in Queensland than in other areas.

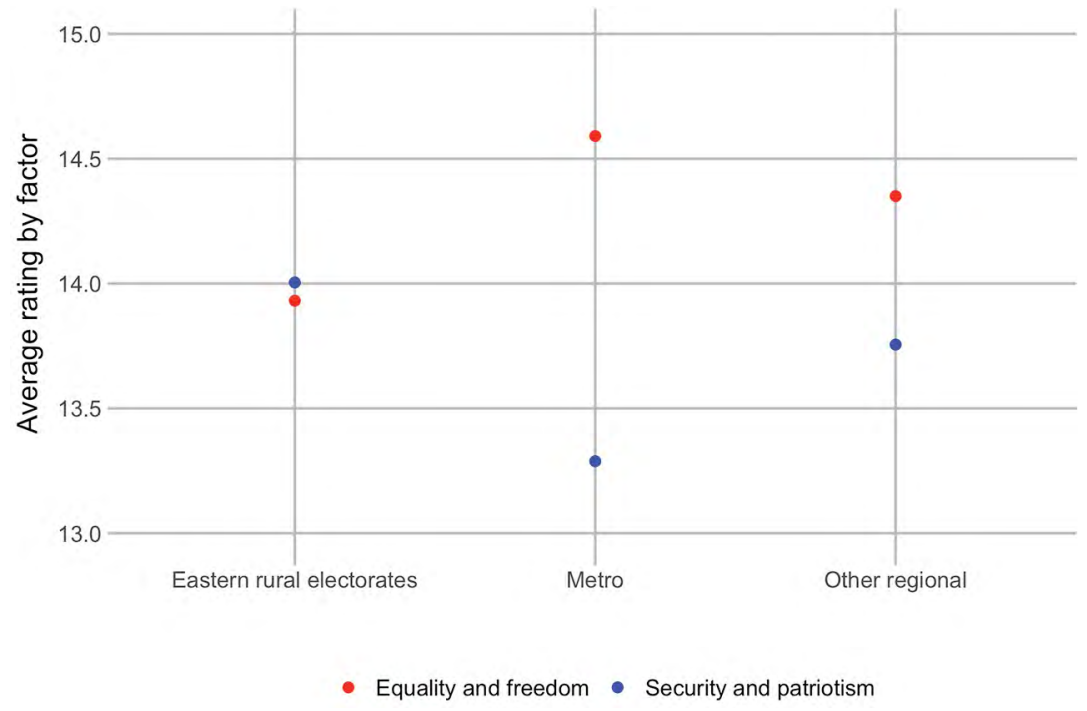

Figure 15.2 Ratings for the factors of 'security and patriotism' and 'equality and freedom'

Source: 2016 survey by Linda Courtenay Botterill, Helen Berry and Geoff Cockfield. 


\section{Conclusion}

The Nationals saved more than the furniture in the 2019 election, preserving the house they had steadily rebuilt since 2007 (see Figure 15.1). They remain a significant party in that they are usually needed for the non-Labor parties to form government and they continue to hold important portfolios in Cabinet. They are able to project values related to social conservatism, nationalism and community, despite members not always living up to those purported values. Anti-Labor sentiment-a foundational element of the Country Party-has now broadened to encompass the Greens and, most recently, animal welfare activism, so that mobilising against this supposed threat axis is now entrenched in popular discourse and campaigning.

The election result, along with a historical tendency to leadership stability, may keep McCormack in place. On the other hand, there may be further agitation, with Joyce remaining ambitious and some of the Queenslanders feeling both entitled and important. They would, however, do well to think about what strategies have worked for the Country Party/Nationals and that is stable coalitions. Efforts at independence, as in Western Australia, have not really worked in even the medium term, nor has direct competition with the Liberals. And, once a State party is extinguished, it can be hard to revive, though there were mergers and demergers in Queensland prior to the LNP that did not cripple the State Country Party/Nationals. The Nationals are, however, unlikely to be able to deliver substantial benefits to the agricultural sector and rural communities given the constraints of coalition, market deregulation, drought, population movement to major towns and cities and the general difficulties of running small businesses. That may not, however, matter so much provided the Nationals are seen as representing agriculture, small business and some notion of the community values of the 'real' Australia.

\section{References}

Australian Electoral Commission (AEC). 2019. 2019 Federal Election Results. Canberra: AEC. www.aec.gov.au/Elections/Federal_Elections/2019/index.htm.

Botterill, Linda Courtenay and Geoff Cockfield. 2015. 'From "Unstable" to "Stable" Minority Government: Reflections on the Role of the Nationals in Federal Coalition Governments'. Australian Journal of Politics and History 61(1): 53-66. doi.org/10.1111/ajph.12086. 
Chan, Gabrielle. 2018. 'Barnaby Joyce accuser Catherine Marriott hailed by WA Nationals as she tells of her pain'. The Guardian, 1 November. www.the guardian.com/australia-news/2018/nov/01/barnaby-joyce-catherine-marriotthailed-wa-nationals-as-she-tells-of-pain.

Clarke, Melissa. 2019. 'Coalition senator's reported threat to Environment Minister could spark Adani appeal, lawyers say'. $A B C$ News, 9 April. www.abc. net.au/news/2019-04-09/lawyers-eye-coalition-threat-as-grounds-for-adaniappeal/10982834.

Cockfield, Geoff. 2009. 'A rural party in an urban nation'. In The National Party: Prospects for the Great Survivors, edited by Linda Courtenay Botterill and Geoff Cockfield, 42-80. Sydney: Allen \& Unwin.

Coorey, Phil. 2019. 'PM concedes to Nats, pledges to consider new coal plant in Qld'. Australian Financial Review, 26 March. www.afr.com/news/ politics/national/pm-pledges-to-consider-a-new-coal-plant-in-queensland20190326-p517j8.

Crowe, David. 2019. "I'm the elected deputy prime minister of Australia”: Barnaby feels no guilt over challenge to Nationals leader'. Sydney Morning Herald, 11 March. www.smh.com.au/politics/federal/i-m-the-elected-deputyprime-minister-of-australia-barnaby-feels-no-guilt-over-challenge-to-nationalsleader-20190311-p5137j.html.

Davies, Ann. 2019. “"The Darling will die”: Scientists say mass fish kill due to over-extraction and drought'. The Guardian, 18 February. www.theguardian. com/australia-news/2019/feb/18/the-darling-will-die-scientists-say-massfish-kill-due-to-over-extraction-and-drought.

Department of the Prime Minister and Cabinet (PM\&C). 2018. Joint Agency Drought Taskforce. Canberra: Australian Government. www.pmc.gov.au/ domestic-policy/joint-agency-drought-taskforce.

Doran, Matthew, Andrew Kesper and Emma Machan. 2019. 'Where have the leaders been and what does it mean for the election?'. $A B C$ News, 18 May. www.abc.net.au/news/2019-05-18/federal-election-campaign-heatmap-showssought-after-seats/11124898.

Foley, Mike. 2019. 'Jail time for animal activists under government's new plan'. The Canberra Times, 10 April. www.canberratimes.com.au/story/6017816/ coalition-pledges-to-lock-up-militant-activists/?cs=14231.

Hamilton-Smith, Lexie. 2018. 'Cotton farm execs accused of $\$ 20 \mathrm{~m}$ fraud over Murray-Darling water funding'. ABC News, 28 August [Updated 9 January 2019]. www.abc.net.au/news/2018-08-28/cotton-executives-20-million-fraudallegation-norman-farming/10172736. 
Irvine, Jessica and Shane Wright. 2019. 'See what the Coalition and Labor are promising in your electorate'. WAToday, 29 April. www.watoday.com.au/ federal-election-2019/see-what-the-coalition-and-labor-are-promising-inyour-electorate-20190422-p51g3z.html.

Karp, Paul. 2019. 'Morrison offers cheap loans to flood-afflicted graziers in north Queensland'. The Guardian, 1 March. www.theguardian.com/australia-news/ 2019/mar/01/morrison-offers-cheap-loans-to-flood-afflicted-graziers-in-northqueensland.

Koziol, Michael. 2019. 'Us versus them: The angry and unpredictable politics of north Queensland'. Sydney Morning Herald, 5 May. www.smh.com.au/ federal-election-2019/us-versus-them-the-angry-and-unpredictable-politicsof-north-queensland-20190502-p51jf2.html.

Livingston, Angus. 2018. 'Malcolm Turnbull pressures Barnaby Joyce to quit'. The Land, 16 February. www.theland.com.au/story/5232061/turnbullpressures-joyce-to-quit/.

McGowan, Michael. 2018. 'NSW Young Nationals expel and suspend members over far-right links'. The Guardian, 15 October. www.theguardian. com/australia-news/2018/oct/15/nsw-young-nationals-expel-and-suspendmembers-over-far-right-links.

Murphy, Katherine. 2019a. “"Do what it takes": Nationals leader defends preference deals with One Nation'. The Guardian, 30 April. www.theguardian. com/australia-news/2019/apr/30/do-what-it-takes-nationals-leader-defendspreference-deals-with-one-nation.

Murphy, Katherine. 2019b. 'Keith Pitt on nuclear power, self-styled experts and how Canberra crushes free thinking'. The Guardian, 12 July. www.theguardian. com/australia-news/2019/jul/12/keith-pitt-on-nuclear-power-self-styledexperts-and-how-canberra-crushes-free-thinking.

Patel, Uma. 2016. 'Adler shotgun: Nationals senator Bridget McKenzie says heavy restrictions are irrational'. $A B C$ News, 10 December. www.abc.net.au/news/ 2016-12-10/bridget-mckenzie-urges-mps-to-vote-against-adler-restrictions/ 8108810 .

Schwartz, Shalom H., Gian Vittoria Caprara and Michele Vecchione. 2010. 'Basic Personal Values, Core Political Values, and Voting: A Longitudinal Analysis'. Political Psychology 31(3): 421-52. doi.org/10.1111/j.1467-9221. 2010.00764.x. 
Schwartz, Shalom H., Gian Vittorio Caprara, Michele Vecchione, Paul Bain, Gabriel Bianchi, Maria Giovanna Caprara, Jan Cieciuch, Hasan Kirmanoglu, Cem Baslevent, Jan-Erik Lönnqvist, Catalin Mamali, Jorge Manzi, Vassilis Pavlopoulos, Tetyana Posnova, Harald Schoen, Jo Silvester, Carmen Tabernero, Claudio Torres, Markku Verkasalo, Eva Vondráková, Christian Welzel and Zbigniew Zaleski. 2014. 'Basic Personal Values Underlie and Give Coherence to Political Values: A Cross National Study in 15 Countries'. Political Behavior 36(4): 899-930. doi.org/10.1007/s11109-013-9255-z.

The Nationals. 2019a. Our plan for a stronger agriculture, fisheries and forestry sector. Press release, 2 May. Canberra: National Party of Australia.

The Nationals. 2019b. Our Plan for Population, Migration and Better Cities. Policy document. Canberra: National Party of Australia.

University of Western Australia (UWA). various years. Australian Politics and Elections Database. Perth: University of Western Australia. elections.uwa. edu.au/.

Wroe, David. 2019. “"Member for Manila”: MP puts overseas travel before key campaign slogan'. Sydney Morning Herald, 18 April. www.smh.com.au/ federal-election-2019/member-for-manila-mp-puts-overseas-travel-beforekey-campaign-slogan-20190417-p51f59.html.

Wroe, David and David Crowe. 2018. 'Nationals MP Andrew Broad to quit parliament over "sugar daddy" scandal'. Sydney Morning Herald, 18 December. www.smh.com.au/politics/federal/nationals-mp-andrew-broad-to-quitparliament-over-sugar-daddy-scandal-20181218-p50mwx.html. 
This text is taken from Morrison's Miracle: The 2019 Australian Federal Election, edited by Anika Gauja, Marian Sawer and Marian Simms, published 2020 by ANU Press, The Australian National University, Canberra, Australia.

doi.org/10.22459/MM.2020.15 